\title{
Myc-enhanced expression of Cul1 promotes ubiquitin-dependent proteolysis and cell cycle progression
}

\author{
Rónán C. O'Hagan, ${ }^{1,2}$ Michael Ohh, ${ }^{1}$ Gregory David, ${ }^{1,2}$ Ignacio Moreno de Alboran, ${ }^{4,5}$ \\ Frederick W. Alt, ${ }^{4,5}$ William G. Kaelin, Jr., ${ }^{1,3}$ and Ronald A. DePinho ${ }^{1,2,6}$ \\ ${ }^{1}$ Department of Adult Oncology, Dana Farber Cancer Institute, Boston, Massachusetts 02115 USA; ${ }^{2}$ Department \\ of Medicine and Genetics, Harvard Medical School, Boston, Massachusetts 02115 USA; $^{3}$ Howard Hughes Medical Institute, \\ Dana Farber Cancer Institute, Boston, Massachusetts 02115 USA; ${ }^{4}$ Howard Hughes Medical Institute, Children's Hospital, \\ Boston, Massachusetts 02115 USA; $^{5}$ Department of Genetics, Harvard Medical School, Boston, Massachusetts 02115 USA
}

The c-Myc oncoprotein plays an important role in the growth and proliferation of normal and neoplastic cells. To execute these actions, $\mathrm{c}-\mathrm{Myc}$ is thought to regulate functionally diverse sets of genes that directly govern cellular mass and progression through critical cell cycle transitions. Here, we provide several lines of evidence that $\mathrm{c}-$ Myc promotes ubiquitin-dependent proteolysis by directly activating expression of the Cul1 gene, encoding a critical component of the ubiquitin ligase $S \mathrm{SF}^{\mathrm{SKP} 2}$. The cell cycle inhibitor $\mathrm{p}^{27^{\mathrm{kip} 1}}$ is a known target of the $\mathrm{SCF}^{\mathrm{SKP} 2}$ complex, and Myc-induced Cul1 expression matched well with the kinetics of declining p2 $7^{\mathrm{kip} 1}$ protein. Enforced Cul1 expression or antisense neutralization of $\mathbf{p} 27^{\mathrm{kip} 1}$ was capable of overcoming the slow-growth phenotype of $\mathrm{c}$-Myc null primary mouse embryonic fibroblasts (MEFs). In reconstitution assays, the addition of in vitro translated Cul1 protein alone was able to restore $227^{\mathrm{kip} 1}$ ubiquitination and degradation in lysates derived from $c$-myc ${ }^{-/-}$MEFs or density-arrested human fibroblasts. These functional and biochemical data provide a direct link between $\mathrm{c}-\mathrm{Myc}$ transcriptional regulation and ubiquitin-mediated proteolysis and together support the view that $c-M y c$ promotes $G_{1}$ exit in part via Cul1-dependent ubiquitination and degradation of the CDK inhibitor, $\mathbf{p} 27^{\mathrm{kip} 1}$.

[Key Words: Myc; Cull; ubiquitin-dependent proteolysis; cell cycle; $27^{\text {kip1}}$ ]

Received June 14, 2000; accepted in revised form July 10, 2000.

That c-Myc plays an integral role in cellular proliferation is understood from its high levels in proliferating cells and low levels in quiescent cells, its rapid increase on growth factor-stimulated proliferation (Obaya et al. 1999), and its ability to stimulate S-phase entry (Eilers et al. 1991) and shorten the cell cycle (Karn et al. 1989). It has become apparent from landmark studies in Drosophila and mammalian cells that c-Myc triggers $G_{1}$ exit in part through its ability to promote an increase in cell mass, a known physiological stimulus for $G_{1}$ exit (Killander and Zetterberg 1965; Iritani and Eisenman 1999; Johnston et al. 1999). A large body of work has also established that c-Myc can modulate the expression of genes controlling the cell cycle and that most of these Myc-responsive targets regulate the activity of the $G_{1}$ CDKs, primarily CDK2, and thereby facilitate transit through the $G_{1} / S$ transition.

Activation of c-Myc in quiescent fibroblasts leads to

${ }^{6}$ Corresponding author.

E-MAIL ron_depinho@dfci.harvard.edu; FAX (617) 632-6069

Article and publication are at www.genesdev.org/cgi/doi/10.1101/ gad. 827200 . the rapid induction of cyclin E/CDK2 kinase activity (Steiner et al. 1995; Muller et al. 1997), findings in accord with the requirement of CDK2 activation for c-Myc to promote $G_{1}$ exit (Rudolph et al. 1996). In contrast, dominant negative mutant alleles of $c-m y c$ or somatic deletion of $c$-myc suppress cyclin E/CDK2 activity (Berns et al. 1997; Mateyak et al. 1997; Moreno et al., unpubl.). c-Myc activation of cyclins D1 and D2 gene expression (Daksis et al. 1994; Hoang et al. 1994) is thought to lead to D-type cyclin sequestration of $\mathrm{p} 27^{\mathrm{kip} 1}$ from the CDK2 complex (Bouchard et al. 1999; Perez-Roger et al. 1999). The c-Myc-responsive target, cdc25a, (Galaktionov et al. 1996) encodes a phosphatase capable of activating both $\mathrm{Cdk} 2$ and Cdk4. Conversely, c-Myc can directly repress transcription of the $p 27 k i p 1$ gene and appears to interfere with p $27^{\text {kip } 1}$ function (Vlach et al. 1996; Leone et al. 1997). Together, these findings indicate that c-Myc facilitates $G_{1}$ exit by positively modulating $G_{1}$ cyclin/ $\mathrm{CDK}$ complexes and, at least in part, by negatively modulating expression of the cell cycle inhibitor p2 $7^{\mathrm{kip} 1}$.

To understand Myc's role in cell cycle progression, we conducted genome-wide expression profiles to identify cell cycle genes that are subject to direct transcriptional regulation by c-Myc. These efforts led us to one such 
Myc-responsive target, Cullin-1 (Cu11; O'Hagan et al. 2000). Cull, an essential component of the SCF ${ }^{\text {SKP2 }}$ complex, was considered to be an attractive target given the link between c-Myc and CDK2 activity and the importance of $\mathrm{SCF}^{\mathrm{Skp} 2}$ in the regulation of $\mathrm{p} 27^{\mathrm{kip} 1}$ protein levels (Carrano et al. 1999; Sutterluty et al. 1999; Tsvetkov et al. 1999). The regulation of $\mathrm{p} 27^{\mathrm{kip} 1}$ polyubiquitination by the $\mathrm{SCF}^{\mathrm{SKP} 2}$ complex is complex and dependent on the prior phosphorylation of p27 on threonine 187 /Vlach et al. 1996; Carrano et al. 1999; Sutterluty et al. 1999; Tsvetkov et al. 1999). Depletion of any of the components of $\mathrm{SCF}^{\mathrm{SKP} 2}$ complex, namely Skp1, Cul1, or Skp2, prevents polyubiquitination and subsequent degradation of p27 $7^{\text {kip1 }}$ (Carrano et al. 1999; Tsvetkov et al. 1999). Moreover, targeted disruption of skp2 leads to accumulation of p2 $7^{\text {kip } 1}$ (Nakayama et al. 2000). Together, these data raised the possibility that the regulation of $\mathrm{p} 27^{\mathrm{kip} 1}$ protein levels is a critical focus of Myc's actions in the cell cycle and that Cull could provide a direct link from c-Myc transactivation activity to the ubiquitination machinery responsible for $\mathrm{p} 27^{\text {kip } 1}$ regulation and to control of $G_{1}$ exit.

\section{Results}

Several studies were conducted to verify that Cull is a direct Myc-responsive gene target. First, the Myc-Estrogen Receptor (Myc-ER) system was used to examine gene expression patterns following 4-hydroxy-tamoxifen (4OHT) induction of Myc under conditions of protein synthesis inhibition by cycloheximide. Addition of
4-OHT to cycloheximide-treated Myc-ER expressing IMR90 cells resulted in a threefold increase in Cul1 mRNA levels and no change in Cul2 gene expression (Fig. 1A), thus suggesting that Myc is capable of directly enhancing Cul1 transcriptional activity. Second, antiCull immunoblots of protein extracts from density- arrested Myc-ER IMR90 cells, induced for $36 \mathrm{hr}$ with ethanol alone or with 4-OHT, indicated that the levels of Cull protein are increased only in association with MycER activation (Fig. 1B). Third, Cull protein was undetectable in c-Myc-deficient MEFs in which the c-myc gene had been acutely deleted by Cre-mediated recombination (Moreno et al., unpubl.) (Fig. 1C). In contrast, activation of the potent Myc antagonist, Mxil-SR, resulted in a threefold lower level of Cul1 gene expression in the presence of cycloheximide, than was observed on activation of the weak repressor form of Mxil, Mxil-WR (devoid of the Sin 3 co-repressor domain; Fig. 1D). Finally, mxi1 ${ }^{-/-}$MEFs expressed higher baseline levels of Cull protein than mxi1 heterozygotes (Fig. 1E).

Next, the human Cul1 promoter was cloned and found to contain a consensus E box predicted to bind Myc and Mad(Mxil) complexes (Blackwell et al. 1990; Fig. 1F). The Cul1 promoter was used to drive expression of the luciferase reporter gene and assayed for Myc and Mxil responsiveness. Myc-ER induction was associated with up to threefold induction of Cul1 reporter activity, while Mxil-ER induction resulted in a maximum 10-fold repression (Fig. 1G). Mutation of the E-box abrogated Myc and Mxil regulation of Cul1 promoter activity (Fig. 1G). These data, together with the above expression studies, indicate that Cul1 is a direct transcriptional target of

Figure 1. Cull is a direct transcriptional target of Myc and Mxil. (A) Cul1 and Cul2 Northern blot of IMR90 Myc-ER cells untreated or treated with $1 \mu \mathrm{M}$ 4-OHT. GAPDH serves as an internal loading control. In addition, no change in the expression of the $\mathrm{SCF}^{\mathrm{SKP} 2}$ complex components SKP2 or CDC34 was detected in genome-wide expression screens for c-MYC responsive gene targets or by Northern blot analysis (data not shown). (B) Cull immunoblot on IMR90 Myc-ER cells uninduced or treated with $1 \mu \mathrm{M}$ 4-OHT. (C) Cull immunoblot on wildtype, or c-mycl-/-) MEFs. (D) Cull Northern blot of IMR90 cells expressing Mxi1-SR-ER or Mxil-WR-ER after induction with $1 \mu M$ 4-OHT. GAPDH serves as an internal loading control. (E) Cull immunoblot on mxil (+/-), and mxi1(-/-) MEFs. $(F)$ Schematic representation of the Cull promoter. The E-box, TATAbox and start sites for transcription (arrow) and translation (ATG) were determined by sequence analysis and are indicated. $(G)$ Histogram representing the ability of Myc and Mxil to regulate the Cull promoter or a mutant in which the

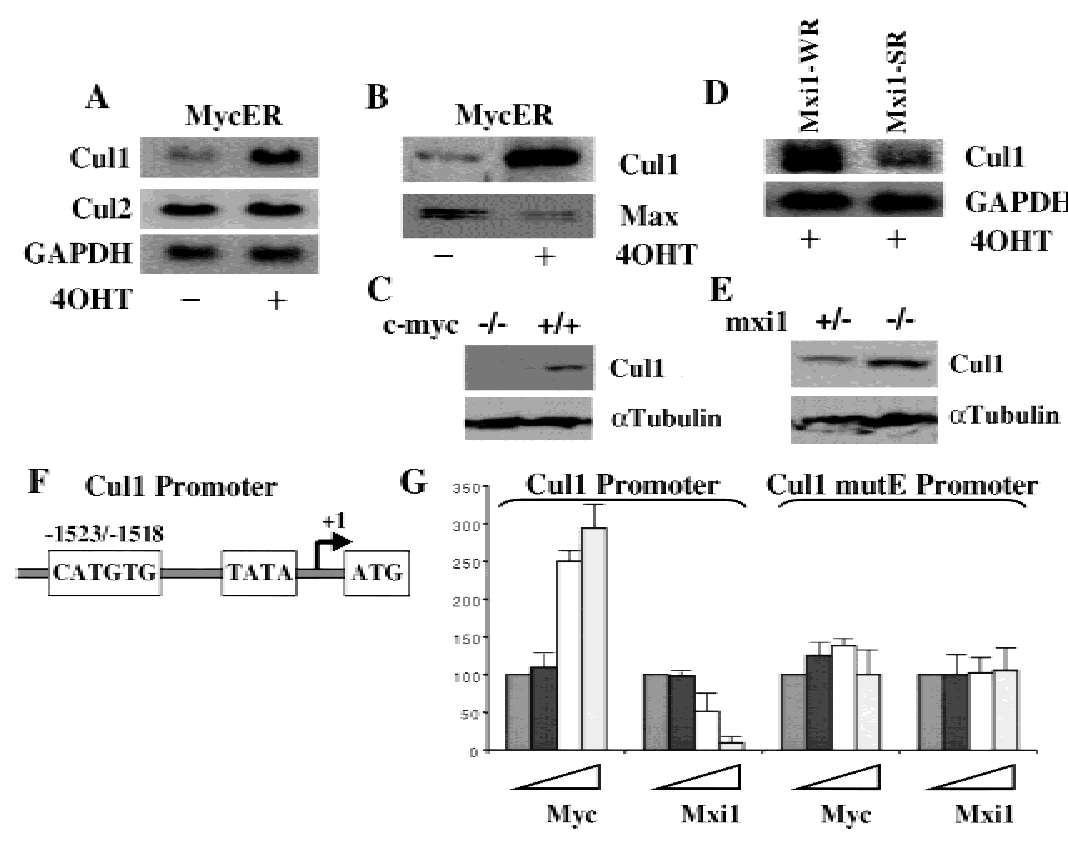
E-box CATGTG has been altered to CACTCA.

Luciferase values were determined by luminometer and corrected for transfection efficiency by $\beta$-galactosidase assay. Values shown are the mean of three experiments plus and minus the standard deviation of the mean. Northern and immunoblot experiments were performed a minimum of two times with identical results. 
both Myc and Mxil. Cul1 belongs to a family of proteins first identified in Caenorhabditis elegans and is implicated in regulation of the $G_{0} / G_{1}$ to $S$ transition of the cell cycle (Kipreos et al. 1996). Deletion of the Cul1 gene in mice causes arrest in early embryogenesis and accumulation of cyclin E (Dealy et al. 1999; Wang et al. 1999). Correspondingly, arrest of cul1(-/-) embryos occurs at approximately the same point of early postimplantation as embryos lacking Myc superfamily function because of deletion of $\max$ (Shen-Li et al. 2000). To examine further the functional relationship between Cull and Myc in control of cell proliferation, we examined the effect of Cull overexpression on the growth characteristics of the slow-growing, low-S-phase $c$-mycl-/-) MEF cultures. In control studies, transduction of $c-m y c|-/-|$ MEFs with a c-Myc-encoding retrovirus led to an increase in the fraction of cells in S phase and restored significant growth potential as measured by the WST1 assay and standard growth curves (Fig. 2). The impact of enforced Cull expression on the S-phase fraction and growth characteristics of $c-m y c(-/-)$ MEFs was equivalent to that of c-Myc (Fig. 2). As p2 $7^{\text {kip } 1}$ is a target for the E3-ubiquitin ligase complex SCF ${ }^{\mathrm{SKP} 2}$, we also tested whether antisense neutralization of $\mathrm{p} 27^{\mathrm{kip} 1}$ could phenocopy the effects of Cull or c-Myc overexpression on c-Myc-deficient MEFs. Indeed, transduction of $c-m y c(-/-)$ MEFs with antisense p27kip1 resulted in reduction of $\mathrm{p} 27^{\mathrm{kip} 1}$ protein levels (Fig. 2B), increase in the S-phase fraction, and restoration of proliferative activity (Fig. 2). The inability of Cyclin A overexpression to restore proliferative activity in $c$-myc (-/-) MEFs supports the proposed specific and critical roles of Cul1 and p27 in Myc regulation of S-phase entry.
The oncogenic capacity of Myc is classically assessed through its ability to cooperate with activated RAS ${ }^{\mathrm{G} 12 \mathrm{~V}}$ to effect the malignant transformation of primary rat embryo fibroblasts (Land et al. 1983) or MEFs null for INK4a (Serrano et al. 1997). Genome-wide expression profiling and site-directed mutation of the DNA binding domain of Myc has supported the view that oncogenic actions of Myc are highly dependent on its ability to regulate many genes governing diverse cellular processes (O'Hagan et al. 2000) Accordingly, we tested whether Cul1 and antisense-p27 could cooperate with oncogenic RAS to transform primary MEFs null for INK4a (Pomerantz et al. 1998). While c-Myc/RAS generated transformed foci in the monolayer, the cotransfection of RAS along with Cul1, antisense-p27, or the cell cycle control gene Cyclin A yielded a background number of transformed foci (data not shown). These findings reinforce the view that the transforming potential of Myc extends beyond its ability to promote $\mathrm{G}_{1}$ exit.

The above complementation assays are consistent with the concept that Cull-mediated $\mathrm{p} 27^{\mathrm{kip} 1}$ degradation is a critical aspect of c-Myc regulation of $G_{1}$ exit and cellular proliferation. This relationship was further substantiated by the kinetics of Cul1 and $27^{\text {kip } 1}$ protein levels in relation to Myc activation. First, proliferating wild-type MEFs expressed detectable Cul1 protein and low p27 kip1 levels, while the slowly proliferating $c$-myc(-/-) MEFs showed a reciprocal pattern of expression (data not shown). Similar results for $\mathrm{p} 27^{\text {kip } 1}$ have been reported in $c$-myc null rat fibroblasts (Mateyak et al. 1999). Second, Myc-ER activation in density-arrested IMR90 cells (which express barely detectable levels of
A

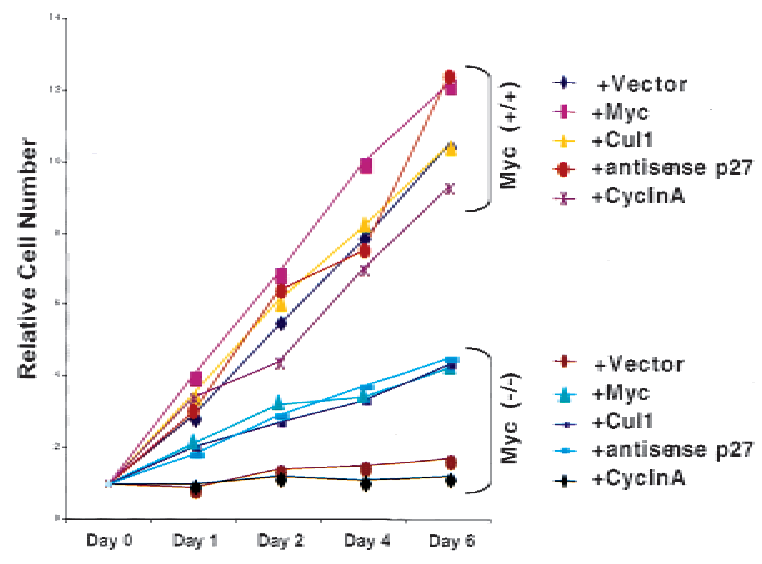

B

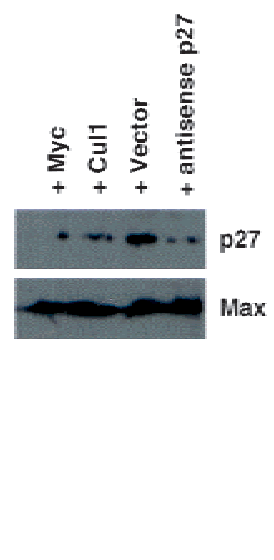

C

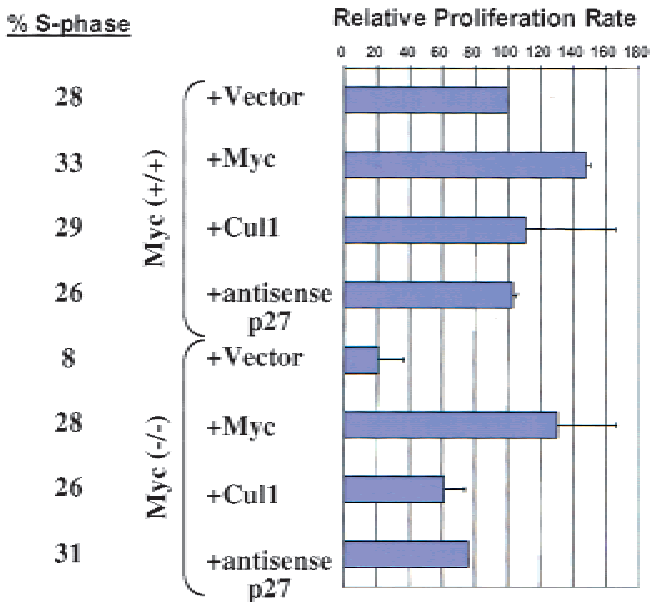

Figure 2. Expression of Cull or inhibition of $\mathrm{p} 27^{\mathrm{kip} 1}$ expression rescues proliferation in c-myc(-/-) MEFs. (A) Wild-type or c-myc(-/-) MEFS infected with retroviruses expressing c-Myc, Cull, or antisense p2 $7^{\mathrm{kip} 1}$ as indicated, were plated at $1 \times 10^{5}$ cells per well in replicate wells and cultured for the indicated number of days. Triplicate wells were trypsinized and counted. Values shown represent the mean of three experiments performed with independently derived MEF lines. (B) p2 $7^{\mathrm{kip} 1}$ immunoblot on myc(-/-) MEFs infected with retrovirus expressing Myc, Cul1, or antisense p2 $7^{\mathrm{kip} 1}$. Immunoblot for Max serves as a loading control. $(C)$ Proliferation rate of wild-type and c-myc(-/-) MEFs infected with retroviruses expressing c-Myc, Cul1, or antisense p2 $7^{\text {kip } 1}$ as indicated. Proliferation was determined using a WST-1 cleavage assay (Boehringer Mannheim). Values shown represent the average of three independent experiments performed with independently derived MEF lines plus and minus the standard deviation of the mean. S-phase fractions were determined by FACS analysis of MEFs after staining with PI. Values shown represent the mean of three experiments with three independently derived MEF lines. 
Cull and high levels of p2 $7^{\text {kip } 1}$ proteins) resulted in increased Cul1 and reduced $\mathrm{p} 27^{\mathrm{kip} 1}$ protein levels and Sphase entry (Fig. 3A). Examination of early time points following Myc-ER activation showed that the increase of Cull protein, first evident at $1 \mathrm{hr}$, precedes the decline in $\mathrm{p} 27^{\mathrm{kip} 1}$ protein levels, first evident at $2 \mathrm{hr}$.

Although these results are consistent with the scenario that Myc induces Cul1, which in turn stimulates $\mathrm{p} 27^{\mathrm{kip} 1}$ degradation, it has also been suggested that Myc can repress transcription of the p27kip1 gene (Li et al. 1994; Lee 1999). Thus, to verify that c-Myc also regulates $\mathrm{p} 27^{\mathrm{kip} 1}$ on the posttranslational level, density-arrested Myc-ER-expressing IMR90 fibroblasts were labeled with 35S-Met and 35S-Cys for $1 \mathrm{hr}$. After the $1 \mathrm{hr}$ pulse, 4-OHT was added to induce Myc-ER activity, and the chase was allowed to proceed for up to $36 \mathrm{hr}$ to follow the kinetics of $\mathrm{p} 27^{\mathrm{kip} 1}$ degradation. $\mathrm{p} 27^{\mathrm{kip} 1}$ protein was present for up to $24 \mathrm{hr}$ in the empty vector controls, whereas in the Myc-ER cultures, $\mathrm{p} 27^{\mathrm{kip} 1}$ protein was undetectable after only $2 \mathrm{hr}$ (Fig. 3B). These results demonstrate that Myc can regulate $\mathrm{p} 27^{\mathrm{kip} 1}$ on the posttranslational level.

As Cul1 stimulates degradation of $\mathrm{p} 27^{\mathrm{kip} 1}$ via ubiquitination-dependent proteolysis (Carrano et al. 1999; Sutterluty et al. 1999; Tsvetkov et al. 1999), we utilized an in vitro ubiquitination assay system to establish that Myc stimulates degradation of $\mathrm{p} 27^{\mathrm{kip} 1}$ via ubiquitination (see Materials and Methods). In this assay, extracts from c-mycl-/-) MEFs or density-arrested IMR90 Myc-ER cells failed to stimulate ubiquitination of $\mathrm{p} 27^{\mathrm{kip} 1}$ despite the addition of cyclinE/CDK2 (Fig. 4A, lanes 2,4; Fig. 4B,

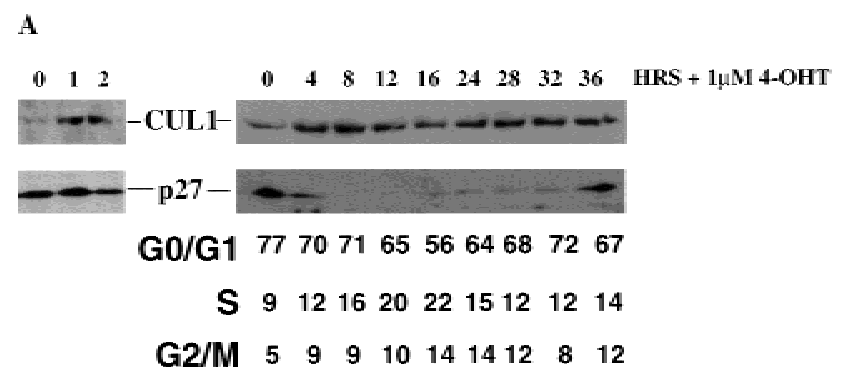

B

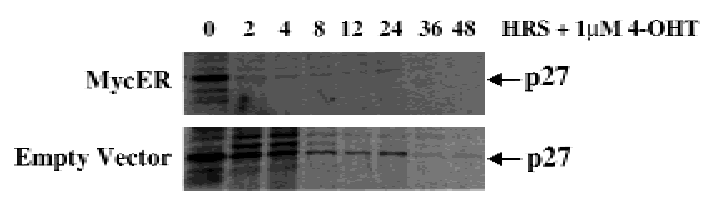

Figure 3. Myc enhances expression of Cull and stimulates degradation of $\mathrm{p} 27^{\mathrm{kip} 1}$. (A) Immunoblot of Cul1 and $\mathrm{p} 27^{\mathrm{kip} 1} \mathrm{ex}-$ pression on extracts from density arrested IMR90 MycER cells induced with $1 \mu \mathrm{M}$ 4-OHT for the indicated times. Cull and p $27^{\text {kip } 1}$ panels were obtained from a single gel. Cell cycle profiles at each time point were determined as described in Materials and Methods. Blot illustrated is representative of three experiments. $(B) \mathrm{p} 27^{\mathrm{kip} 1}$ protein was immunoprecipitated from density-arrested IMR90 cells containing MycER or empty vector that were metabolically labeled as described in Materials and Methods and then chased in the presence of $1 \mu \mathrm{M} 4-\mathrm{OHT}$ for the indicated times. lanes 2,3). In contrast, extracts from wild-type MEFs or 4-OHT-treated Myc-ER IMR90 cells stimulated robust ubiquitination of p2 $7^{\text {kip } 1}$ (Fig. 4A, lanes 3,5; Fig. 4B, lanes $5,6)$. These differences were not caused by general defects in protein ubiquitination activity as extracts from wild-type and $c$-myc(-/-) MEFs, and uninduced and induced Myc-ER IMR90 cells support the ubiquitination of p53 (Fig. 4D, cf. lanes 1 and 3 with lanes 2 and 4). Most important, addition of in vitro synthesized Cull protein to the extracts from c-myc null MEFs or density-arrested Myc-ER IMR90 cells rescued the ability of these extracts to stimulate ubiquitination of $\mathrm{p} 27^{\mathrm{kip} 1}$ (Fig. 4A, cf. lanes 2 and 4 with lanes 6 and 8; Fig. 4B, cf. lanes 2 and 3 with lanes 8 and 9). In contrast, addition of in vitro synthesized Cul2 protein did not stimulate ubiquitination of p2 $7^{\text {kip } 1}$ (Fig. 4C). These data strongly suggest that Cull is a critical downstream target of Myc's actions on $\mathrm{p} 27^{\mathrm{kip} 1}$.

\section{Discussion}

Genetic studies have positioned the actions of Myc upstream of or at the RB-regulated $\mathrm{G}_{1} / \mathrm{S}$ transition (Lahoz et al. 1994). However, our understanding of the mechanisms through which Myc engages the core components of the cell cycle machinery remains incomplete. Using genome expression profile analysis of c-Myc activation, we recently identified Cul-1 as a direct transcriptional target of c-Myc (O'Hagan et al. 2000). Here, we demonstrate that Myc-enhanced expression of Cul-1 promotes ubiquitin-dependent degradation of $\mathrm{p} 27^{\mathrm{kip} 1}$. Overexpression of Cul1 or antisense inhibition of $\mathrm{p} 27^{\mathrm{kip} 1}$ rescued the slow-growth phenotype associated with c-myc null mouse embryo fibroblasts and was equivalent to exogenous c-Myc replacement. Moreover, Cull expression was sufficient for Myc-induced ubiquitination and subsequent degradation of $\mathrm{p} 27^{\mathrm{kip} 1}$. These data provide a direct link between c-Myc transactivation activity and the core cell cycle machinery integral to the regulation of $G_{1}$ exit.

The ubiquitin system drives the cell division cycle by the timely destruction of numerous cell cycle regulatory proteins (Elledge and Harper 1998). The SCF complex plays a critical role in this process by catalyzing substrate ubiquitination in the cell cycle (Krek 1998). It is clear that changes in expression of the F-box protein Skp2 play a major role in regulating the $G_{1} / S$ transition by affecting p2 $7^{\mathrm{kip} 1}$ ubiquitination (Amati and Vlach 1999; Carrano et al. 1999; Sutterluty et al. 1999; Nakayama et al. 2000). However, no change in the expression of the SCF ${ }^{\mathrm{SKP} 2}$ complex components SKP2, RBX1, or CDC34 was detected in genome-wide expression screens for c-MYC responsive gene targets or by Northern blot analysis (data not shown). The biological and biochemical data presented here indicate that Myc's ability to directly modulate the level of Cull, albeit modestly, represents the critical point through which Myc promotes $\mathrm{G}_{1}$ exit, specifically via $\mathrm{SCF}^{\mathrm{Skp} 2}$-mediated polyubiquitination and degradation of $\mathrm{p} 27^{\mathrm{kip} 1}$. These functional and biochemical findings help clarify a key feature of the circuitry that connects c-Myc to the Rb- 


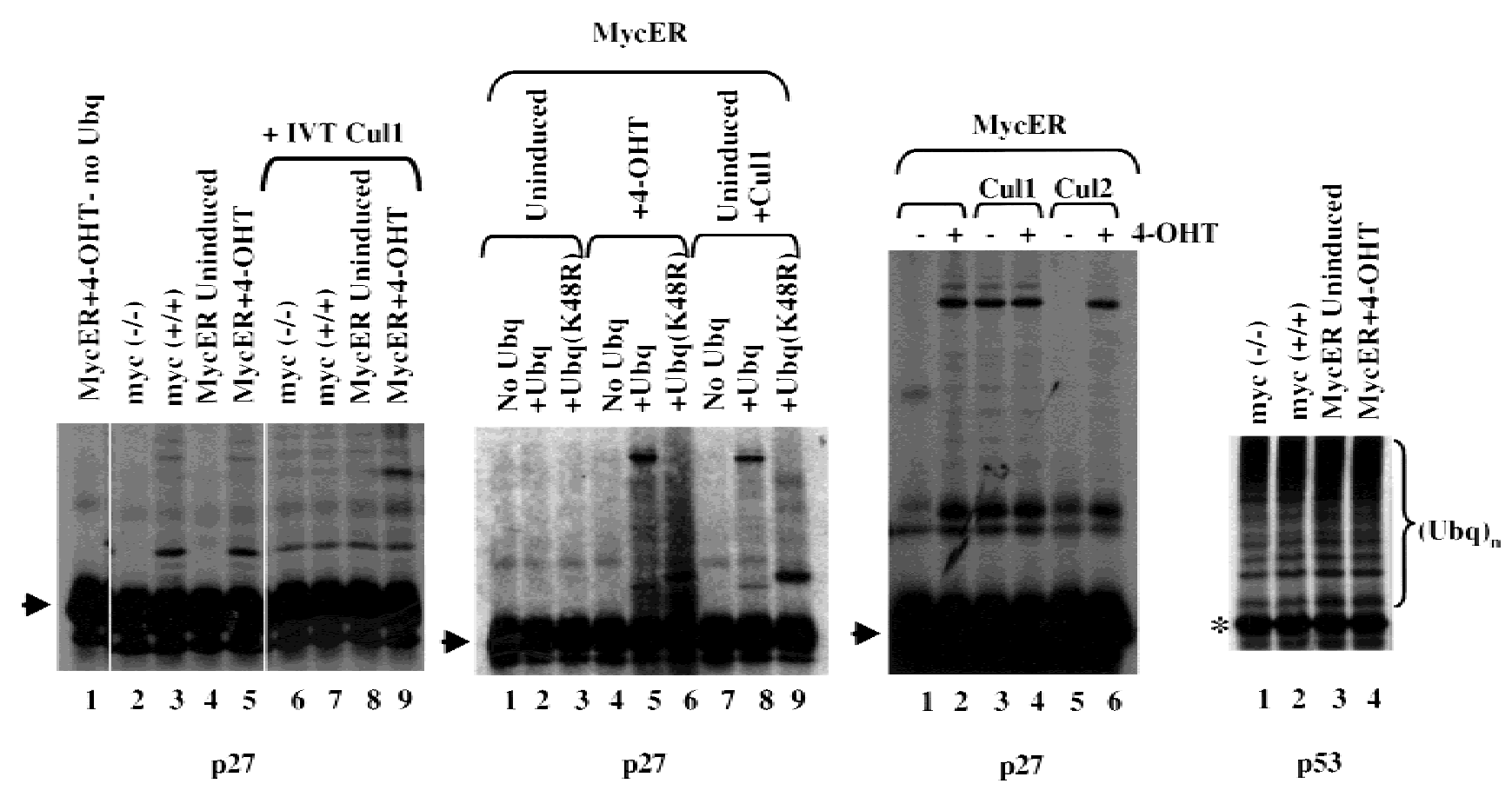

Figure 4. Cul1 is sufficient for Myc-dependent ubiquitination of $\mathrm{p} 27^{\mathrm{kip} 1}$. (A) Ubiquitination of ${ }^{35} \mathrm{~S}$-labeled p $27^{\mathrm{kip} 1}$ was monitored in the presence of the indicated S100 cell extracts. Unlabeled Cull was added to the reactions in the lanes indicated. As a control, no purified ubiquitin was added to the reaction in lane 1. Following the in vitro ubiquitination reaction, p2 $7^{\mathrm{kip} 1}$ was precipitated, resolved on SDS-PAGE, and detected by autoradiography. The three panels shown are from the same autoradiogram exposure of a single gel. Input p $27^{\text {kip } 1}$ is indicated by the arrow. (B) Ubiquitination of ${ }^{35}$ S-labeled p27kip1 in the presence of the indicated S100 extracts. K48R-ubiquitin was added where indicated to prevent polyubiquitination. Input p $27^{\mathrm{kip} 1}$ is indicated by the arrow. $(C)$ Ubiquitination of ${ }^{35}$ S-labeled p $27^{\mathrm{kip} 1}$ in the presence of the indicated S100 extracts. Unlabeled Cul1 or Cul2 was added to the reactions in the lanes indicated. Input $\mathrm{p} 27^{\mathrm{kip} 1}$ is indicated by the arrow. $(D)$ Ubiquitination of ${ }^{35} \mathrm{~S}$-labeled p53 in the presence of S100 extracts prepared from wild-type and $c$-myc(-/-) MEFs, and IMR90 MycER cells treated as indicated. Asterisk indicates input p53. Polyubiquitinated forms are indicated as $(\mathrm{Ubq})_{n}$. All ubiquitination experiments were performed a minimum of three times with identical results.

regulated restriction point, the most critical decision point in the mammalian cell cycle.

It has been established that low or absent $\mathrm{p} 27^{\mathrm{kip} 1}$ protein levels portend a poor prognosis in a variety of human carcinomas including those of the colon and breast (Catzavelos et al. 1997; Loda et al. 1997; Mori et al. 1997; Porter et al. 1997; Steeg and Abrams 1997). p2 $7^{\text {kip } 1}$ protein degradation activity, rather than p27kip1 mRNA abundance, predicts the observed differences in $\mathrm{p} 27^{\mathrm{kip} 1}$ protein levels in the tumors examined to date. Our study raises the possibility that differences in $\mathrm{p} 27^{\mathrm{kip} 1}$ degradation activity among human tumors reflect differential activation of c-Myc and consequent up-regulation of Cull. If this is indeed the case, then prediction of tumor biological behavior might be improved by also examining the level of Cull along with its additional downstream targets.

\section{Materials and methods}

\section{Cell culture}

Embryonic day 13.5 mouse embryo fibroblasts and IMR90 and NIH 3 T3 cells were grown in Dulbecco's Modified Eagle Me- dium (DMEM) (GIBCO BRL) supplemented with $15 \%$ fetal bovine serum (FBS), $0.29 \mathrm{mg} / \mathrm{ml}$ L-glutamine, $0.03 \%$ penicillin and streptomycin, and $25 \mu \mathrm{g} / \mathrm{ml}$ gentamycin sulfate. Myc-ER and Mxil-ER induction studies were performed as described (O’Hagan et al. 2000).

\section{Reporter assays}

NIH 3T3 cells were transfected using LipoFectamine reagent (Life Science Technologies) with $100 \mathrm{ng}$ of a luciferase reporter bearing nucleotides -1600 to +400 of the Cullin 1 promoter, 200 ng of pCMX- $\beta$-galactosidase, and either 35,100 or $300 \mathrm{ng}$ of pcDNA3 (Invitrogen) encoding c-Myc or Mxil. Empty pcDNA3 vector was included in each transfection to a total of 600ng of DNA per transfection. $\beta$-galactosidase activity was assayed by incubation of whole-cell extracts with $400 \mu \mathrm{g} / \mathrm{ml}$ ONPG in buffer containing $60 \mathrm{mM} \mathrm{Na}_{2} \mathrm{HPO}_{4}, 40 \mathrm{~mm} \mathrm{NaH} \mathrm{PO}_{4}, 10 \mathrm{~mm}$ $\mathrm{KCl}$, and $1 \mathrm{mM} \mathrm{MgSO}_{4}$ and relative transfection efficiencies determined by reading absorbance at $415 \mathrm{~nm}$.

\section{Retroviral infection}

pBABE-Myc, pBABE-Cul1, and pBABE-antisense-p27kip1 viruses were harvested from transiently transfected $\phi \mathrm{X}$ cell lines. All transductions with ecotropic retrovirus were carried out according to Serrano et al. (1997). 


\section{Northern blot}

RNA was extracted from IMR90 cells $8 \mathrm{hr}$ after induction by 4-OHT and prepared using the RNeasy Midi kit (Qiagen), followed by extraction with Triazol (Life Science Technologies), and then ethanol precipitation. Twenty micrograms of total RNA was separated by electrophoresis in a $0.8 \%$ agarose $2.2 \mathrm{M}$ formaldehyde gel and transferred onto nitrocellulose. Membranes were hybridized with ${ }^{32} \mathrm{P}$-labeled probes.

\section{Immunoblots}

To assay the amount of Cull or p2 $7^{\mathrm{kip} 1}$ expressed in MEFs or IMR90 cells, cells were collected and lysed in ice-cold buffer containing 1\% NP40; 50 mm Tris- $\mathrm{HCl}$ (pH 7.4); $400 \mathrm{~mm} \mathrm{NaCl}$; $2 \mu \mathrm{g} / \mathrm{ml} \mathrm{PMSF}$; and $1 \mu \mathrm{g} / \mathrm{ml}$ each of leupeptin, pepstatin, and aprotinin; and resolved by electrophoresis in $8 \%-16 \%$ SDSpolyacrylamide gels and transferred to PVDF membranes by electroblotting. All proteins were detected using the ECL chemiluminescence system (Amersham) and antibodies to Cull (NeoMarkers), p2 $7^{\text {kipl }}$ (Transduction Labs), Max (Santa Cruz), or $\alpha$-tubulin.

\section{Growth curves, cell cycle, and proliferation assays}

Mouse embryonic fibroblasts were isolated from individual 13.5-day embryos. c-myc was deleted using Cre-recombinase as described in Moreno et al. (unpubl.) and c-Myc, Cull, or antisense $\mathrm{p} 27^{\mathrm{kip} 1}$, introduced by transient retroviral infections as described above. For growth curves, early passage MEFs were seeded at $5 \times 10^{4}$ cells per $60-\mathrm{mm}$ dish. At the indicated times, triplicate plates of cells were trypsinized and counted. Cell cycle profiles were obtained by FACS analysis of PI-stained cells. Proliferation rates were measured using a WST-1 cleavage assay (Boehringer Mannheim) according to manufacturer's instructions.

\section{Pulse-chase}

IMR90 cells containing Myc-ER or an empty vector were density arrested for $48 \mathrm{hr}$, maintained in methionine- and cysteinefree media for $1 \mathrm{hr}$, metabolically labeled with $300 \mu \mathrm{Ci}{ }^{35} \mathrm{~S}$ labeled methionine and cysteine (NEN Life Science) for $1 \mathrm{hr}$, and then chased in complete medium containing $1 \mu \mathrm{M}$ 4-OHT for the indicated times. p2 $7^{\mathrm{kip} 1}$ protein was immunoprecipitated from $500 \mu \mathrm{g}$ total protein at each time point, resolved by electrophoresis in 8\%-16\% SDS-polyacrylamide gels, and transferred to PVDF membranes by electroblotting prior to autoradiography.

\section{Preparation of S100 cell extracts}

IMR90 Myc-ER cells -/+ 4-OHT, mycl-/-), and mycl+/+) MEFs were resuspended in ice-cold hypotonic buffer $(20 \mathrm{~mm}$ Tris at $\mathrm{pH} 7.4,5 \mathrm{~mm} \mathrm{MgCl}_{2}, 8 \mathrm{~mm} \mathrm{KCl}, 0.5 \mathrm{~mm}$ PMSF, $10 \mu \mathrm{g} / \mathrm{ml}$ leupeptin, $1 \mu \mathrm{g} / \mathrm{ml}$ pepstatin, $10 \mu \mathrm{g} / \mathrm{ml}$ aprotinin) for $15 \mathrm{~min}$. The cells were freeze/thawed three times and pelleted by centrifugation at $14,000 \mathrm{~g}$ for $5 \mathrm{~min}$ at $4^{\circ} \mathrm{C}$. The resulting supernatant was then ultracentrifuged at $100,000 \mathrm{~g}$ for $4 \mathrm{hr}$ at $4^{\circ} \mathrm{C}$. The supernatant (S100 fraction) was aliquoted and stored at $-80^{\circ} \mathrm{C}$.

\section{In vitro ubiquitination assay.}

In vitro translated ${ }^{35}$ S-labeled His-tagged p27kip1 $(3 \mu 1)$ was incubated in S100 extracts (100 $\mu \mathrm{g})$ supplemented with ubiquitin

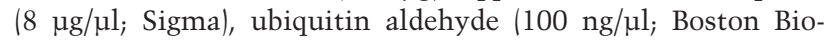
chem), energy regenerating system (ERS; $20 \mathrm{~mm}$ Tris at $\mathrm{pH} 7.4$, $2 \mathrm{~mm}$ ATP, $5 \mathrm{~mm} \mathrm{MgCl}_{2}, 40 \mathrm{~mm}$ creatine phosphate, and 0.5 $\mu \mathrm{g} / \mu \mathrm{l}$ creatine kinase), $1 \mu \mathrm{M}$ okadaic acid, and $0.5 \mu \mathrm{M}$ CyclinE/ $\mathrm{CDK} 2$ in a reaction volume of $30 \mu \mathrm{l}$ for $1-2 \mathrm{hr}$ at $30^{\circ} \mathrm{C}$. Unla- beled in vitro translated Cull or Cul2 ( $2 \mu 1)$ was added to the above reaction as described in the figures. His-tagged $\mathrm{p} 27^{\mathrm{kip} 1}$ products were captured with $\mathrm{Ni}^{2+}$ agarose, resolved by SDSpolyacrylamide gel electrophoresis, and detected by autoradiography.

\section{Acknowledgments}

We thank S. Lowe for the mouse ecotropic receptor, S. Hann for the pBabe- cMycER plasmid, A. Carrano for technical advice, J. $\mathrm{K}$. Lee for technical assistance, and members of the DePinho laboratory for helpful comments. R.C.O. is a recipient of a fellowship from the Jane Coffin Childs Memorial Fund for Medical Research. M.O. is a National Cancer Institute of Canada Fellow. G.D. is a recipient of a fellowship from the Human Frontier Science Program Organization. I.M.A. is a recipient of a fellowship from the Spanish Ministry of Education and is a Howard Hughes Medical Institute Associate. This work was supported by grants to F.W.A. (AI35714), W.G.K. (R01CA68490), and R.A.D. (R01HD28317, R01EY09300) from the National Institutes of Health. F.W.A. and W.G.K. are Investigators of the Howard Hughes Medical Institute. R.A.D. is an American Cancer Society Research Professor.

The publication costs of this article were defrayed in part by payment of page charges. This article must therefore be hereby marked "advertisement" in accordance with 18 USC section 1734 solely to indicate this fact.

\section{Note added in proof}

Ectopic expression of SKP2 was not capable of rescuing proliferation in c-myc(-/-) MEFs (data not shown) or in c-myc null Ratla cells (Berns et al. 2000). Moreover, addition of in vitro synthesized SKP2 to S100 extracts of density-arrested Myc-ER IMR90 cells did not rescue the ability of these extracts to stimulate ubiquitination of $\mathrm{p} 27^{\mathrm{kip} 1}$ (data not shown).

\section{References}

Amati, B. and Vlach, J. 1999. Kip1 meets SKP2: New links in cell-cycle control. Nat. Cell Biol. 1: E91-E93.

Berns, K., Hijmans, E.M., and Bernards, R. 1997. Repression of c-Myc responsive genes in cycling cells causes G1 arrest through reduction of cyclin E/CDK2 kinase activity. Oncogene 15: 1347-1356.

Berns, K., Hijmans, E.M., Koh, E., Daley, G.Q., and Bernards, R. 2000. A genetic screen to identify genes that rescue the slow growth phenotype of c-myc null fibroblasts. Oncogene 19: $3330-3334$.

Blackwell, T.K., Kretzner, L., Blackwood, E.M., Eisenman, R.N., and Weintraub, H. 1990. Sequence-specific DNA binding by the c-Myc protein. Science 250: 1149-1151.

Bouchard, C., Thieke, K., Maier, A., Saffrich, R., Hanley-Hyde, J., Ansorge, W., Reed, S., Sicinski, P., Bartek, J., and Eilers, M. 1999. Direct induction of cyclin D2 by Myc contributes to cell cycle progression and sequestration of p27. EMBO J. 18: $5321-5333$.

Carrano, A.C., Eytan, E., Hershko, A., and Pagano, M. 1999. SKP2 is required for ubiquitin-mediated degradation of the CDK inhibitor p27. Nat. Cell Biol. 1: 193-199.

Catzavelos, C., Bhattacharya, N., Ung, Y.C., Wilson, J.A., Roncari, L., Sandhu, C., Shaw, P., Yeger, H., Morava-Protzner, I., et al. 1997. Decreased levels of the cell-cycle inhibitor p27Kip1 protein: Prognostic implications in primary breast cancer. Nat. Med. 3: 227-230.

Daksis, J.I., Lu, R.Y., Facchini, L.M., Marhin, W.W., and Penn, L.J. 1994. Myc induces cyclin D1 expression in the absence 
of de novo protein synthesis and links mitogen-stimulated signal transduction to the cell cycle. Oncogene 9: 3635-3645.

Dealy, M.J., Nguyen, K.V., Lo, J., Gstaiger, M., Krek, W., Elson, D., Arbeit, J., Kipreos, E.T., and Johnson, R.S. 1999. Loss of Cull results in early embryonic lethality and dysregulation of cyclin E. Nat. Genet. 23: 245-248.

Eilers, M., Schirm, S., and Bishop, J.M. 1991. The MYC protein activates transcription of the alpha-prothymosin gene. EMBO I. 10: 133-141.

Elledge, S.J. and Harper, J.W. 1998. The role of protein stability in the cell cycle and cancer. Biochim. Biophys. Acta 1377: M61-M70.

Galaktionov, K., Chen, X., and Beach, D. 1996. Cdc25 cell-cycle phosphatase as a target of c-myc. Nature 382: 511-517.

Hoang, A.T., Cohen, K.J., Barrett, J.F., Bergstrom, D.A., and Dang, C.V. 1994. Participation of cyclin A in Myc-induced apoptosis. Proc. Nat1. Acad. Sci. 91: 6875-6879.

Iritani, B.M. and Eisenman, R.N. 1999. c-Myc enhances protein synthesis and cell size during B lymphocyte development. Proc. Natl. Acad. Sci. 96: 13180-13185.

Johnston, L.A., Prober, D.A., Edgar, B.A., Eisenman, R.N., and Gallant, P. 1999. Drosophila myc regulates cellular growth during development. Cell 98: 779-790.

Karn, J., Watson, J.V., Lowe, A.D., Green, S.M., and Vedeckis, W. 1989. Regulation of cell cycle duration by c-myc levels. Oncogene 4: 773-787.

Killander, D. and Zetterberg, A. 1965. A quantitative cytochemical investigation of the relationship between cell mass and initiation of DNA synthesis in mouse fibroblasts in vitro. Exp. Cell Res. 40: 12-20.

Kipreos, E.T., Lander, L.E., Wing, J.P., He, W.W., and Hedgecock, E.M. 1996. cul-1 is required for cell cycle exit in C. elegans and identifies a novel gene family. Cell 85: 829-839.

Krek, W. 1998. Proteolysis and the G1-S transition: The SCF connection. Curr. Opin. Genet. Dev. 8: 36-42.

Lahoz, E.G., Xu, L., Schreiber-Agus, N., and DePinho, R.A. 1994. Suppression of Myc, but not Ela, transformation activity by Max-associated proteins, Mad and Mxil. Proc. Natl. Acad. Sci. 91: 5503-5507.

Land, H., Parada, L.F., and Weinberg, R.A. 1983. Tumorigenic conversion of primary embryo fibroblasts requires at least two cooperating oncogenes. Nature 304: 596-602.

Lee, L.A. and Dang, C.V. 1997. c-Myc transrepression and cell transformation. Curr. Top. Microbiol. Immunol. 224: 131-135.

Leone, G., DeGregori, J., Sears, R., Jakoi, L., and Nevins, J.R. 1997. Myc and Ras collaborate in inducing accumulation of active cyclin E/Cdk2 and E2F. Nature 387: 422-426.

Li, L.H., Nerlov, C., Prendergast, G., MacGregor, D., and Ziff, E.B. 1994. c-Myc represses transcription in vivo by a novel mechanism dependent on the initiator element and Myc box II. EMBO J. 13: 4070-4079.

Loda, M., Cukor, B., Tam, S.W., Lavin, P., Fiorentino, M., Draetta, G.F., Jessup, J.M., and Pagano, M. 1997. Increased proteasome-dependent degradation of the cyclin-dependent kinase inhibitor p27 in aggressive colorectal carcinomas. Nat. Med. 3: 231-234.

Mateyak, M.K., Obaya, A.J., Adachi, S., and Sedivy, J.M. 1997. Phenotypes of c-Myc-deficient rat fibroblasts isolated by targeted homologous recombination. Cell Growth Differ. 8: 1039-1048.

Mateyak, M.K., Obaya, A.J., and Sedivy, J.M. 1999. c-Myc regulates cyclin D-Cdk4 and -Cdk6 activity but affects cell cycle progression at multiple independent points. Mol. Cell Biol. 19: 4672-4683.

Mori, M., Mimori, K., Shiraishi, T., Tanaka, S., Ueo, H., Sugimachi, K., and Akiyoshi, T. 1997. p27 expression and gastric carcinoma. Nat. Med. 3: 593.

Muller, D., Bouchard, C., Rudolph, B., Steiner, P., Stuckmann, I., Saffrich, R., Ansorge, W., Huttner, W., and Eilers, M. 1997. Cdk2-dependent phosphorylation of p27 facilitates its Mycinduced release from cyclin $\mathrm{E} / \mathrm{cdk} 2$ complexes. Oncogene 15: 2561-2576.

Nakayama, K., Nagahama, H., Minamishima, Y.A., Matsumoto, M., Nakamichi, I., Kitagawa, K., Shirane, M., Tsunematsu, R., Tsukiyama, T., Ishida, N., et al. 2000. Targeted disruption of Skp2 results in accumulation of cyclin $\mathrm{E}$ and p27(Kip1), polyploidy and centrosome overduplication. EMBO I. 19: 2069-2081.

Obaya, A.J., Mateyak, M.K., and Sedivy, J.M. 1999. Mysterious liaisons: The relationship between c-Myc and the cell cycle. Oncogene 18: 2934-2941.

O'Hagan, R.C., Schreiber-Agus, N., Chen, K., David, G., Engelman, J.A., Schwab, R., Alland, L., Thomson, C., Ronning, D.R., Sacchettini, J.C., et al. 2000. Gene-target recognition among members of the myc superfamily and implications for oncogenesis. Nat. Genet. 24: 113-119.

Perez-Roger, I., Kim, S.H., Griffiths, B., Sewing, A., and Land, H. 1999. Cyclins D1 and D2 mediate myc-induced proliferation via sequestration of $\mathrm{p} 27(\mathrm{Kip} 1)$ and $\mathrm{p} 21$ (Cip1). EMBO $J$. 18: $5310-5320$.

Pomerantz, J., Schreiber-Agus, N., Liegeois, N.J., Silverman, A., Alland, L., Chin, L., Potes, J., Chen, K., Orlow, I., Lee, H.W., et al. 1998. The Ink4a tumor suppressor gene product, p19Arf, interacts with MDM2 and neutralizes MDM2's inhibition of p53. Cell 92: 713-723.

Porter, P.L., Malone, K.E., Heagerty, P.J., Alexander, G.M., Gatti, L.A., Firpo, E.J., Daling, J.R., and Roberts, J.M. 1997. Expression of cell-cycle regulators p27Kip1 and cyclin E, alone and in combination, correlate with survival in young breast cancer patients. Nat. Med. 3: 222-225.

Rudolph, B., Saffrich, R., Zwicker, J., Henglein, B., Muller, R., Ansorge, W., and Eilers, M. 1996. Activation of cyclin-dependent kinases by Myc mediates induction of cyclin A, but not apoptosis. EMBO J. 15: 3065-3076.

Serrano, M., Lin, A.W., McCurrach, M.E., Beach, D., and Lowe, S.W. 1997. Oncogenic ras provokes premature cell senescence associated with accumulation of p53 and p16INK4a. Cell 88: 593-602.

Shen-Li, H., O’Hagan, R.C., Hou Jr., H., Horner II, J.W., Lee, H.W., and DePinho, R.A. 2000. Essential role for Max in early embryonic growth and development. Genes \& Dev. 14: 17-22.

Steeg, P.S. and Abrams, J.S. 1997. Cancer prognostics: Past, present and p27. Nat. Med. 3: 152-154.

Steiner, P., Philipp, A., Lukas, J., Godden-Kent, D., Pagano, M., Mittnacht, S., Bartek, J., and Eilers, M. 1995. Identification of a Myc-dependent step during the formation of active G1 cyclin-cdk complexes. EMBO J. 14: 4814-4826.

Sutterluty, H., Chatelain, E., Marti, A., Wirbelauer, C., Senften, M., Muller, U., and Krek, W. 1999. p45SKP2 promotes p27Kip1 degradation and induces S phase in quiescent cells. Nat. Cell Biol. 1: 207-214.

Tsvetkov, L.M., Yeh, K.H., Lee, S.J., Sun, H., and Zhang, H. 1999. p27(Kip1) ubiquitination and degradation is regulated by the SCF(Skp2) complex through phosphorylated Thr187 in p27. Curr. Biol. 9: 661-664.

Vlach, J., Hennecke, S., Alevizopoulos, K., Conti, D., and Amati, B. 1996. Growth arrest by the cyclin-dependent kinase inhibitor p27Kip1 is abrogated by c-Myc. EMBO J. 15: 6595-6604.

Wang, Y., Penfold, S., Tang, X., Hattori, N., Riley, P., Harper, J.W., Cross, J.C., and Tyers, M. 1999. Deletion of the Cull gene in mice causes arrest in early embryogenesis and accumulation of cyclin E. Curr. Biol. 9: 1191-1194. 


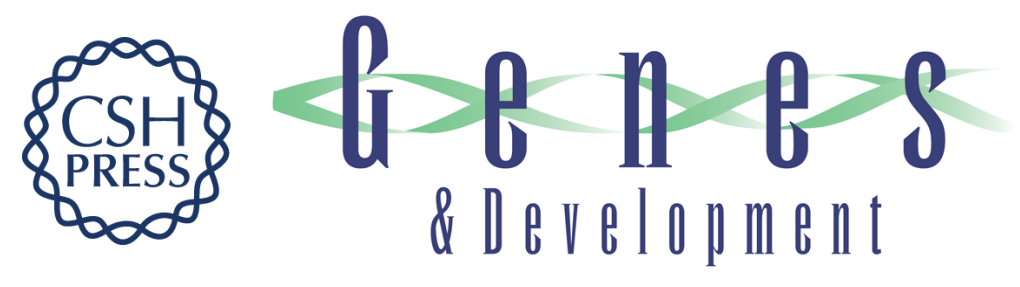

\section{Myc-enhanced expression of Cul1 promotes ubiquitin-dependent proteolysis and cell cycle progression}

Rónán C. O'Hagan, Michael Ohh, Gregory David, et al.

Genes Dev. 2000, 14:

Access the most recent version at doi:10.1101/gad.827200

References

This article cites 44 articles, 10 of which can be accessed free at: http://genesdev.cshlp.org/content/14/17/2185.full.html\#ref-list-1

License

Email Alerting

Receive free email alerts when new articles cite this article - sign up in the box at the top Service right corner of the article or click here.

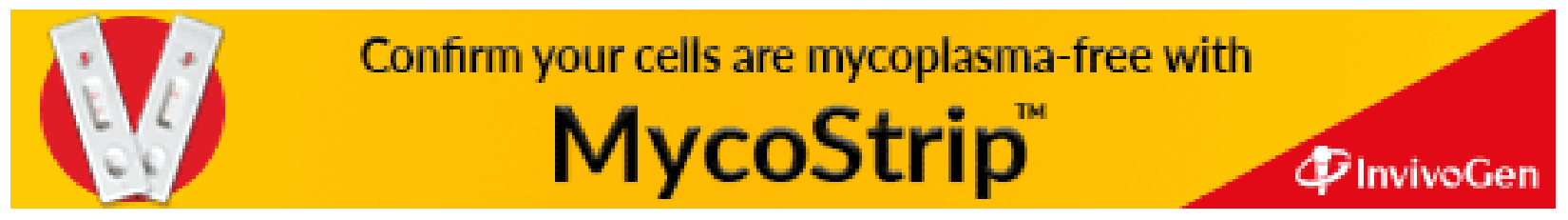

